\title{
Hydroxy-Thioxanthones as Suitable Neutral Ionophores for the Preparation of PVC-Membrane Potentiometric Sensors for Al(III) Ion
}

\author{
Mojtaba Shamsipur, *广 Sohrab Ershad,* Absollah Yari,* Hashem SharghI,** and \\ Ali Reza Salimi**
}

*Department of Chemistry, Razi University, Kermanshah, Iran

**Department of Chemistry, Shiraz University, Shiraz, Iran

\begin{abstract}
The complexation of five recently synthesized hydroxy-thioxanthone derivatives with $\mathrm{Al}^{3+}$ ion was studied in a methanol solution spectrophotometrically, and the stepwise formation constants of the resulting 1:1 and 2:1 (ligand-to-metal) complexes were evaluated. The suitability of the thioxanthone derivatives as neutral ionophores for the preparation of a new $\mathrm{Al}^{3+}$ ion-selective PVC-membrane electrode was investigated, and 1-hydroxy-3-methyl-thiocanthone was selected as the best compound for this purpose. The prepared electrode exhibits a Nernstian response for $\mathrm{Al}^{3+}$ ions over a wide concentration range $\left(2.0 \times 10^{-2}\right.$ to $\left.2.0 \times 10^{-6} \mathrm{M}\right)$, with a limit of detection of $1.0 \times 10^{-6} \mathrm{M}$. It has a very fast response time of about $5 \mathrm{~s}$ and can be used for at least 3 months without any considerable divergence in the potentials. The proposed membrane sensor revealed very good selectivities for $\mathrm{Al}^{3+}$ over a wide variety of other metal ions, and could be used at a working $\mathrm{pH}$ range of 3.4 -5.0. It was used as an indicator electrode in potentiometric titration of aluminum ions with EDTA, and in the determination of $\mathrm{Al}^{3+}$ in different real samples.
\end{abstract}

(Received June 10, 2003; Accepted September 19, 2003)

\begin{abstract}
During the past decade, the analysis of trace metal ions has become a real challenge due to the specificity, accuracy and sensitivity required by ever more stringent regulations. ${ }^{1-3}$ The toxicological effects of metal ions, such as aluminum, on living system, especially on human beings, are now well known. Several recent epidemiological studies investigated the correlation between the uptake of aluminum ions, mostly from drinking water, and the Alzheimer's and Parkinson's diseases, as well as dialysis diseases. ${ }^{4-8}$ Because aluminum is still used as a flocculating agent in potable water treatment units, there is an increasing need for aluminum monitoring in treated and raw water samples. ${ }^{9-11}$ Aluminum monitoring and speciation is also of vital importance in the aluminum industry as a source for light metal materials and light alloys ${ }^{12}$ and in ecological impacts of aluminum. ${ }^{13,14}$

Aluminum determination in water samples is generally carried out with classical techniques, such as atomic absorption or emission spectrometry. However, these methods are very time and money consuming, and do not permit real-time or even onsite determinations. Ion-selective electrodes based on solvent polymeric membranes with the incorporation of specific ion carriers have been shown to be very useful tools for metal-ion analyses in different samples, ${ }^{15-18}$ due to their ease of preparation, simple operation, reasonable selectivity, relatively fast response and low cost. Despite the urgent need for $\mathrm{Al}^{3+}$ ion-selective electrodes for fast and accurate monitoring of aluminum in different industrial, medicinal and environmental samples, there are only limited reports in the literature on $\mathrm{Al}^{3+}$ sensors to directly determine the aluminum concentration. ${ }^{19-22}$
\end{abstract}

$\doteqdot$ To whom correspondence should be addressed.

E-mail: mshamsipur@yahoo.com
Thioxanthone (TX) derivatives have been shown to possess very useful medicinal properties..$^{23,24}$ They have been introduced in such processes as surface coating, printing inks, photoresistors and microelectronics. ${ }^{25}$ Several TX derivatives have been synthesized and examined in terms of their efficiency as photoinitiators. ${ }^{26-28}$ However, to the best of our knowledge, there is no previous report on the use of TX derivatives as ion carriers in such analytical applications as ion transport through liquid membranes and the preparation of ion-selective electrodes.

Very recently, we have reported on new PVC-based ionselective electrodes for some trivalent metal ions, including $\mathrm{Ce}^{3+},{ }^{29} \mathrm{Fe}^{3+},{ }^{31}$ and $\mathrm{Yb}^{3+} .{ }^{32}$ In this work we found that the recently synthesized thioxanthone derivatives 1-hydroxythioxanthone (TX1), 1,3-dihydroxy-thioxanthone (TX2), 1,4dihydroxy-thioxanthone (TX3), 1,4-dihydroxy-3-methylthioxanthone (TX4) and 1-hydroxy-3-methyl-thioxanthone (TX5) (Fig. 1) can form highly selective 2:1 (TX: metal ion) complexes with $\mathrm{Al}^{3+}$ ion in a methanol solution. Thus, due to their water insolubility and high tendency for $\mathrm{Al}^{3+}$ complexation, we examined thioxanthones TX1 - TX5 as neutral ionophores for the preparation of PVC-based membrane sensors for $\mathrm{Al}^{3+}$. The membrane based on TX5 resulted in the best response characteristics for aluminum ion.

\section{Experimental}

Reagents

Reagent-grade nitrophenyl octyl ether (NPOE), dibutyl phthalate (DBP), acetophenone (AP), oleic acid (OA), sodium tetraphenylborate (STPB), high relative molecular weight PVC 


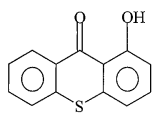

TX1

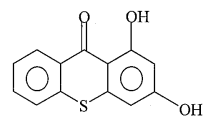

$\mathrm{TX} 2$

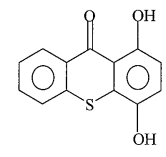

TX3

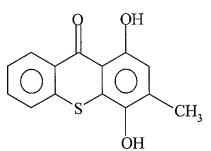

TX4

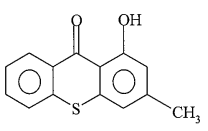

TX5
Fig. 1 Structure of thioxanthone derivatives.

tetraethylammonium perchlorate (TEAP) and tetrahydrofuran (THF) were purchased from Fluka Chemical Company and used as received. The nitrate salts of all cations used (all from Merck) were of the highest purity available and used without any further purification, except for vacuum drying. Doubly distilled deionized water was used throughout.

\section{Synthesis of hydroxy-thioxanthones}

The thioxanthone derivatives TX1 - TX5 were synthesized and purified as described elsewhere. ${ }^{33}$

General procedure. To a mixture of $\mathrm{CH}_{3} \mathrm{SO}_{3} \mathrm{H} 98 \%(2 \mathrm{ml})$ and $\mathrm{Al}_{2} \mathrm{O}_{3}$ (acidic type, $0.3 \mathrm{~g}$ ) were added thiosalicylic acid $(0.154 \mathrm{~g}$, $1 \mathrm{mmol})$ and then appropriate phenol $(1 \mathrm{mmol})$. The mixture was stirred and heated in an oil bath at $110-120^{\circ} \mathrm{C}$ for $5-30$ min. The mixture was poured into water and extracted two times with ethyl acetate $(20 \mathrm{ml})$. The organic layer was washed with a saturated solution of sodium bicarbonate $(20 \mathrm{ml})$. The organic layer was dried with calcium chloride and evaporated in vacuum to give a residue, which was not a pure product. Further purification of the products was carried out by simple silica-gel column chromatography.

\section{Selected spectral data for thioxanthone derivatives}

TX1. Yellow powder, $65 \%$ yield. $\mathrm{Mp}=118-120^{\circ} \mathrm{C} .{ }^{1} \mathrm{H}$ NMR $\left(\mathrm{CDCl}_{3}\right): \delta 6.91(\mathrm{~d}, 1 \mathrm{H}) ; 7.04(\mathrm{~d}, 1 \mathrm{H}) ; 7.47(\mathrm{t}, 3 \mathrm{H}) ; 7.50(\mathrm{t}, 1 \mathrm{H})$; $7.52(\mathrm{~d}, 1 \mathrm{H}) ; 7.63(\mathrm{t}, 1 \mathrm{H}) ; 8.25(\mathrm{~d}, 1 \mathrm{H}) ; 14.06(\mathrm{~s}, 1 \mathrm{H}) .{ }^{13} \mathrm{C}$ MNR $\left(\mathrm{CDCl}_{3}\right): \delta 114.2,116.3,126.4,127.2,127.5,129,134.0,136.0$, 137.5, 138.3, 164.5, and 185.3. IR (KBr); $v_{\max }$ : 1620 (s), 1580 (s), 1450 (s), 1350 (s), 1250 (s), 1180 (s), 900 (s), 830 (s), 780 (s), $720(\mathrm{~s}) . \mathrm{MS} m / z=228\left(100 \%\right.$ base peak, $\left.\mathrm{M}^{+}\right), 200(17.2 \%)$, and $171(36.1 \%)$. UV $\left(\lambda_{\max } \mathrm{nm}\right): 262, \varepsilon=64480 ; 313, \varepsilon=$ 21520; 408, $\varepsilon=9240$.

TX2. Yellow powder, $70 \%$ yield. $\mathrm{Mp}=228-232^{\circ} \mathrm{C} .{ }^{1} \mathrm{H}$ NMR $\left(\right.$ DMSO- $\left._{6}\right) \delta: 6.26(\mathrm{~s}, 1 \mathrm{H}), 6.53(\mathrm{~s}, 1 \mathrm{H}), 7.47(\mathrm{t}, 1 \mathrm{H}), 7.63(\mathrm{~m}$, $2 \mathrm{H}), 8.33(\mathrm{~d}, 1 \mathrm{H}), 11.01(\mathrm{~s}, 1 \mathrm{H})$ and $14.36(\mathrm{~s}, 1 \mathrm{H}) .{ }^{13} \mathrm{C} \mathrm{NMR}$ (DMSO-d $\mathrm{d}_{6}$ ): $\delta$ 101.4, 103.3, 107.8, 126.0, 126.9, 127.6, 128.71, 133.4, 136.6, 140.3, 164.2, 166.9, 183.3. IR (KBr): $v_{\max }: 1640$ (s), 1590 (s), 1440 (s), 1270 (s), 1200 (s), 1160 (s), 1020 (s), 900 (s), 840 (s), 750 (s), 700 (s). MS m/z: 244 (10.4\%, M+), 216 (4.9\%), 187 (9.9\%), 115 (10.8\%), 85 (16.7\%), 69 (49.7\%), and 43 (100\% base peak). UV ( $\left.\lambda_{\max } \mathrm{nm}\right): 267, \varepsilon=54360 ; 390, \varepsilon=$ 6000.

TX3. Yellow powder, $70 \%$ yield. $\mathrm{Mp}=266-278^{\circ} \mathrm{C} .{ }^{1} \mathrm{H}$ NMR $\left(\right.$ DMSO-d $\left._{6}\right): \delta 6.87(\mathrm{~d}, 1 \mathrm{H}), 7.24(\mathrm{~d}, 1 \mathrm{H}), 7.60(\mathrm{t}, 1 \mathrm{H}), 7.8(\mathrm{t}$, $1 \mathrm{H}), 7.98(\mathrm{~d}, 1 \mathrm{H}), 8.48(\mathrm{~d}, 1 \mathrm{H}), 10.43(\mathrm{~s}, 1 \mathrm{H}), 13.35(\mathrm{~s}, 1 \mathrm{H})$. ${ }^{13} \mathrm{C}$ NMR (DMSO- $\mathrm{d}_{6}$ ): $\delta 113.4,114.0,121.5,124.3,127.1$, $127.3,127.62,128.9,133.9,138.1,144.1,157.3,185.5$. IR (KBr); v $v_{\max }: 1630$ (s), 1580 (s), 1480 (s), 1450 (s), 1350 (s), 1220 (s), 910 (s), 800 (s), 740 (s), 710 (s). MS m/z: 244 (100\% base peak, $\left.\mathrm{M}^{+}\right), 187(18.4 \%)$ and $115(16.1 \%)$. UV $\left(\lambda_{\max } \mathrm{nm}\right)$ :
$255, \varepsilon=25933 ; 273, \varepsilon=16533 ; 339, \varepsilon=10822 ; 439, \varepsilon=3377$. TX4. Yellow powder, $40 \%$ yield. $\mathrm{Mp}=238-240^{\circ} \mathrm{C}$. ${ }^{1} \mathrm{H}$ NMR $\left(D_{M S O} \mathrm{~d}_{6}\right): \delta 2.33(\mathrm{~s}, 3 \mathrm{H}), 6.78(\mathrm{~s}, 1 \mathrm{H}), 7.57(\mathrm{t}, 1 \mathrm{H}), 7.75(\mathrm{t}$, 1H), $7.87(\mathrm{~d}, 1 \mathrm{H}), 8.45(\mathrm{~d}, 1 \mathrm{H}), 9.26(\mathrm{~s}, 1 \mathrm{H}), 13.47(\mathrm{~s}, 1 \mathrm{H}) .{ }^{13} \mathrm{C}$ NMR (DMSO-d $\left.{ }_{6}\right): \delta 17.5,114.8,126.9,127.3,127.4,128.7$, $133.7,135.4,138.2,141.3,158.3,185.2$. IR (KBr); $v_{\max }: 1640$ (s), 1580 (s), 1360 (s), 1300 (s), $1230 \mathrm{v}, 1180$ (s), 920 (s), 850 (m), 780 (s), 730 (s). MS m/z: 258 (100\% base peak, $\left.\mathrm{M}^{+}\right), 242$ (42.7\%), 213 (35.1\%), 184 (15.9\%), 115 (10.47\%), 89 (12.7\%), $69(27.4 \%)$ and $50(32.7 \%)$. UV ( $\left.\lambda_{\max } \mathrm{nm}\right): 255, \varepsilon=31551$; $273, \varepsilon=26925 ; 323, \varepsilon=7270 ; 424, \varepsilon=3936$.

TX5. Yellow crystal, $70 \%$ yield. $\mathrm{Mp}=148-150^{\circ} \mathrm{C}$. ${ }^{1} \mathrm{H}$ NMR $\left(\mathrm{CDCl}_{3}\right): \delta 2.41 ;(\mathrm{s}, 3 \mathrm{H}), 6.71 ;(\mathrm{s}, 1 \mathrm{H}), 6.83 ;(\mathrm{s}, 1 \mathrm{H}), 8.25 ;(\mathrm{d}$ $1 \mathrm{H}), 14.00(\mathrm{~s}, 1 \mathrm{H}) .{ }^{13} \mathrm{C} \mathrm{NMR}\left(\mathrm{CDCl}_{3}\right): \delta 22.5,115.3,115.3$, $116.5,116.5,125.9,126.6,129.7,133.1,145.0,163.0 . \quad$ IR $(\mathrm{KBr})$; $v_{\max }: 1630(\mathrm{~s}), 1580$ (s), $1490(\mathrm{~m}), 1450$ (s), 1410 (s), 1350 (s), 1300 (m), 1190 (s), 900 (s), 860(s), 840 (s), 750 (s), 700 (s). MS m/z: 242 (100\% base peak, $\left.\mathrm{M}^{+}\right), 213$ (21.5\%), 184 (12.6\%) and $43(13.7 \%)$. UV ( $\left.\lambda_{\max } \mathrm{nm}\right): 268, \varepsilon=40240 ; 313, \varepsilon$ $=14480 ; 405, \varepsilon=5520$.

\section{Preparation of electrodes}

The general procedure to prepare the PVC membranes was to thoroughly mix $32 \mathrm{mg}$ of powdered PVC, $58 \mathrm{mg}$ of NPOE, 3 $\mathrm{mg}$ of TX and $7 \mathrm{mg}$ of OA in $5 \mathrm{ml}$ of THF. The resulting mixture was transferred into a glass dish of 2-cm diameter. The solvent was slowly evaporated until an oily concentrated mixture was obtained. A polyethylene tube of 5-mm i.d. was dipped into the mixture for about $10 \mathrm{~s}$, so that a transparent membrane of about $0.3 \mathrm{~mm}$ thickness was formed. After removing the tube from the mixture, it was kept at room temperature for about $1 \mathrm{~h}$. The tube was then filled with an internal filling solution $\left(1.0 \times 10^{-3} \mathrm{M} \mathrm{Al}^{3+}\right)$. The electrode was finally conditioned for $24 \mathrm{~h}$ by soaking in a $1.0 \times 10^{-2} \mathrm{M}$ solution of aluminum nitrate. A silver/silver chloride electrode was used as an internal reference electrode.

\section{Emf measurements}

All emf measurements were carried out with the following cell assembly:

$\mathrm{Ag}-\mathrm{AgCl}|\mathrm{KCl}(3 \mathrm{M})|$ internal solution, $1.0 \times 10^{-3} \mathrm{M} \mathrm{Al}\left(\mathrm{NO}_{3}\right)_{3} \mid$ PVC membrane | test solution $\left|\mathrm{Hg}-\mathrm{HgCl}_{2}\right| \mathrm{KCl}$ (satd.)

A Metrohm ion analyzer $\mathrm{pH} / \mathrm{mV}$ meter was used for potential measurements at $25.0 \pm 0.1^{\circ} \mathrm{C}$. Activities were calculated according to the Debye-Hückel procedure. ${ }^{34}$

\section{Spectrophotometric measurements}

All UV-Vis spectra and the absorbance measurements at fixed wavelengths were carried out on a computerized CECIL spectrophotometer 9000, equipped with an electrical thermostat system. In all measurements, the cell was thermostated at 25.0 $\pm 0.1^{\circ} \mathrm{C}$.

The ionic strength of all thioxanthone and aluminum nitrate solutions in methanol was adjusted by TEAP at a $3.5 \times 10^{-2} \mathrm{M}$. The addition of concentrated $\mathrm{Al}^{3+}$ solutions $\left(5.2 \times 10^{-3} \mathrm{M}\right)$ to a fixed concentration of TX5 $\left(1.7 \times 10^{-4} \mathrm{M}\right)$ was carried out using a pre-calibrated micropipette.

\section{Results and Discussion}

In preliminary experiments, it was found that the addition of some half an equivalent amount of $\mathrm{Al}^{3+}$ to methanol solutions of 


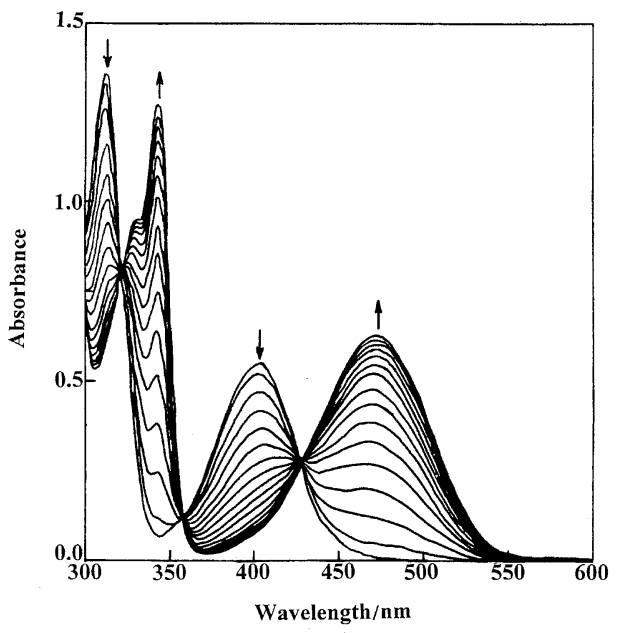

Fig. 2 Electronic spectra of a $1.67 \times 10^{-4} \mathrm{M}$ solution of TX5 in $\mathrm{MeOH}$ in the presence of increasing concentrations of $\mathrm{Al}^{3+}$ from 0.0 to $3.34 \times 10^{-4} \mathrm{M}$.

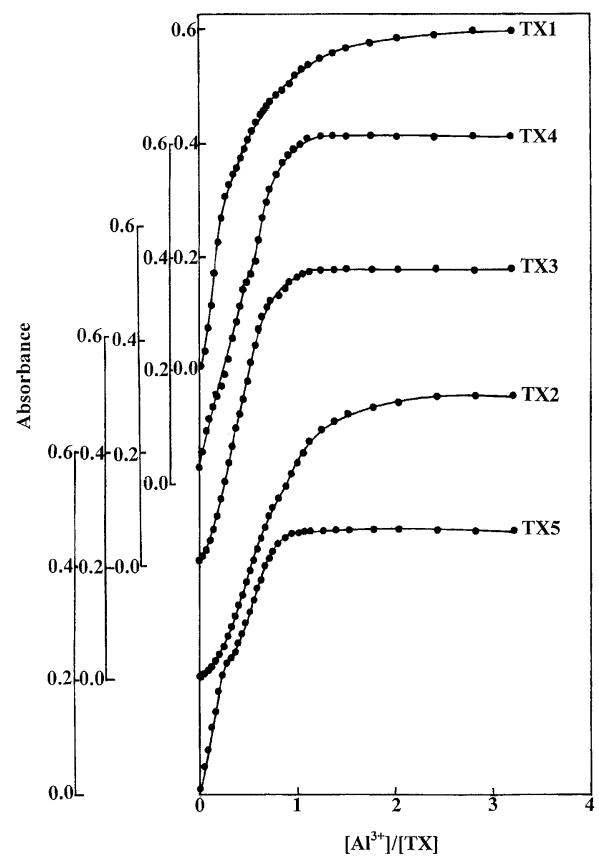

Fig. 3 Absorbance $v s .\left[\mathrm{Al}^{3+}\right] /[\mathrm{TX}]$ molar ratio plots for different thioxanthone derivatives in a $\mathrm{MeOH}$ solution.

TX1 - TX5 $\left(\sim 10^{-4} \mathrm{M}\right)$ resulted in a fast change in the color of the solution from pale yellow to red, while the presence of alkaline earth and transition-metal ions, such as $\mathrm{Mg}^{2+}, \mathrm{Ca}^{2+}$, $\mathrm{Co}^{2+}, \mathrm{Mn}^{2+}, \mathrm{Co}^{2+}, \mathrm{Ni}^{2+}, \mathrm{Pb}^{2+}, \mathrm{Cd}^{2+}$ and $\mathrm{Cr}^{3+}$, showed no observable color change in the thioxanthone solutions. This is most possibly indicative of a selective complex formation of the thioxanthone derivatives with $\mathrm{Al}^{3+}$ ion in a methanol solution.

In order to determine the stoichiometry and stability of the resulting TX complexes with $\mathrm{Al}^{3+}$ ion in a methanol solution, the spectra of a series of solutions containing a constant concentration of ligand $\left(1.7 \times 10^{-4} \mathrm{M}\right)$ at a fixed ionic strength of $3.5 \times 10^{-2} \mathrm{M}$ (maintained by TEAP) and $25^{\circ} \mathrm{C}$ and varying amounts of the metal ion were obtained (example spectra are shown in Fig. 2). As can be seen, the complexation was accompanied by a relatively strong shift of the absorption band
Table 1 Stepwise formation constants for 1:1 $\left(K_{1}\right)$ and 2:1 $\left(K_{2}\right)$ complexes of $\mathrm{Al}^{3+}$ with different thioxanthone derivatives in methanol solution ${ }^{\mathrm{a}}$

\begin{tabular}{ccc}
\hline Thioxanthone & $\log K_{1}$ & $\log K_{2}$ \\
\hline TX1 & 5.57 & 3.08 \\
TX2 & 5.59 & 3.10 \\
TX3 & 5.75 & 3.52 \\
TX4 & 5.78 & 3.49 \\
TX5 & 5.77 & 3.69 \\
\hline
\end{tabular}

a. Standard deviation on $\log K$ values is at the most \pm 0.05 .

of the TX, with two $\lambda_{\max }$ at 313.2 and 404.5 in methanol solution, towards longer wavelengths (i.e., $\lambda_{\max }=343.5$ and $473.8 \mathrm{~nm}$, respectively). Such a pronounced effect on the electronic spectra of the thioxanthone derivative could be related to a large change in the conjugation of the ligand molecule brought about by its complexation with $\mathrm{Al}^{3+}$ ion. ${ }^{35}$

The absorbance $v s .\left[\mathrm{Al}^{3+}\right] /[\mathrm{TX}]$ mole ratio plots obtained at a wavelength of $474 \mathrm{~nm}$ for different thiaxanthone derivatives in methanol solution are shown in Fig. 3. As can be seen from Fig. 3, in the case of all thioxanthone derivatives, the absorbance-mole ratio plots revealed two distinct inflection points at $\left[\mathrm{Al}^{3+}\right] /[\mathrm{TX}]$ molar ratios of about 1 and 0.5 , emphasizing the formation of both 1:1 and 2:1 (ligand-to-metal) complexes in solution, respectively. The formation of $1: 1$ and 2:1 thixanthone-to- $\mathrm{Al}^{3+}$ complexes in a methanol solution was further confirmed by using the continuous variation method (Job's method). The formation constants of the resulting complexes between $\mathrm{Al}^{3+}$ and TX1-TX5 were evaluated by computer fitting of the corresponding mole ratio data to a previously derived equation ${ }^{36}$ using a non-linear curve-fitting program, KINFIT. ${ }^{37}$ The resulting $K_{1}$ and $K_{2}$ values for all complexes are summarized in Table 1. As is obvious from Table 1, the stability of the resulting thioxanthone complexes with $\mathrm{Al}^{3+}$ ion varies in the order TX5 $>\mathrm{TX} 4=\mathrm{TX} 3>\mathrm{TX} 2 \cong$ TX1.

To investigate the suitability of the thioxanthone derivatives TX1 - TX5 as aluminum ion carries in the PVC membranes, five different membrane electrodes (with the same membrane compositions) with these potential ionophores were prepared, and their potential responses were obtained (Fig. 4). As can be seen from Fig. 4, under similar experimental conditions, the membrane based on thioxanthone TX5 shows a Nernstian potential-concentration behavior over a wide concentration range of $10^{-2}-10^{-6} \mathrm{M}$. However, the other thioxanthones resulted in either super Nernstian (e.g., TX1 and TX2) or subNernstian slopes (e.g., TX3 and TX4), although in much narrower linear concentration ranges. It should be noted that TX5 possesses the highest lipophilicity and the highest aluminum complex stability among the five thioxanthone derivatives tested. Thus, the thioxanthone derivative TX5 was selected for the preparation of aluminum selective electrodes.

To investigate the potential response and selectivity of the thioxanthone TX5 for different metal ions, it was used as a neutral ionophore to prepare PVC membrane electrodes for a wide variety of cations, including alkali, alkaline earth, transition and heavy metal ions. The potential responses of TX5-based ion-selective electrodes for various ions are shown in Fig. 5. As is obvious, except for the $\mathrm{Al}^{3+}$ ion, in all other cases, the slope of the corresponding potential-pM plot was much lower than the expected Nernstian slopes of 59, 29.5 and $19.5 \mathrm{mV}$ per decade for mono-, bi- and trivalent cations, respectively, although over a very limited concentration range. 
Table 2 Optimization of a membrane in gradients for TX5

\begin{tabular}{|c|c|c|c|c|c|c|}
\hline \multirow{2}{*}{$\begin{array}{c}\text { Membrane } \\
\text { number }\end{array}$} & \multicolumn{4}{|c|}{ Composition, \% } & \multirow{2}{*}{ Slope/mV decade ${ }^{-1}$} & \multirow{2}{*}{ Linear range/M } \\
\hline & PVC & Plasticizer & TX5 & Additive & & \\
\hline 1 & 29 & NPOE, 64 & - & $7(\mathrm{OA})$ & - & - \\
\hline 2 & 35 & NPOE, 62 & 3 & - & 18.0 & $2 \times 10^{-6}-6 \times 10^{-4}$ \\
\hline 3 & 32 & NPOE, 58 & 3 & $7(\mathrm{OA})$ & 19.7 & $3 \times 10^{-6}-2 \times 10^{-2}$ \\
\hline 4 & 29 & NPOE, 52 & 3 & $16(\mathrm{OA})$ & 20.0 & $2 \times 10^{-6}-2 \times 10^{-2}$ \\
\hline 5 & 30 & NPOE, 62 & 1 & $7(\mathrm{OA})$ & 12.0 & $1 \times 10^{-6}-3 \times 10^{-4}$ \\
\hline 6 & 29 & DBP, 61 & 3 & $7(\mathrm{OA})$ & 21.5 & $2 \times 10^{-6}-2 \times 10^{-3}$ \\
\hline 7 & 30 & AP, 60 & 3 & $7(\mathrm{OA})$ & 10.4 & $2 \times 10^{-5}-2 \times 10^{-3}$ \\
\hline 8 & 33 & NPOE, 62 & 3 & 2(STPB) & 15.0 & $1 \times 10^{-6}-2 \times 10^{-4}$ \\
\hline 9 & 28 & NPOE, 64 & 3 & $5(\mathrm{STPB})$ & 10.0 & $1 \times 10^{-6}-1 \times 10^{-4}$ \\
\hline
\end{tabular}

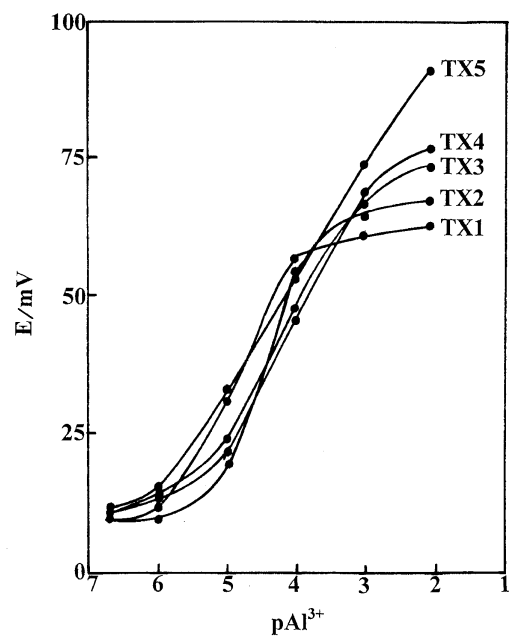

Fig. 4 Potential response of different PVC-membrane electrodes based on TX1 - TX5 for $\mathrm{Al}^{3+}$ ion. The membrane composition was: $32 \%$ PVC, $58 \%$ NPOE, $3 \%$ TX, $7 \%$ OA.

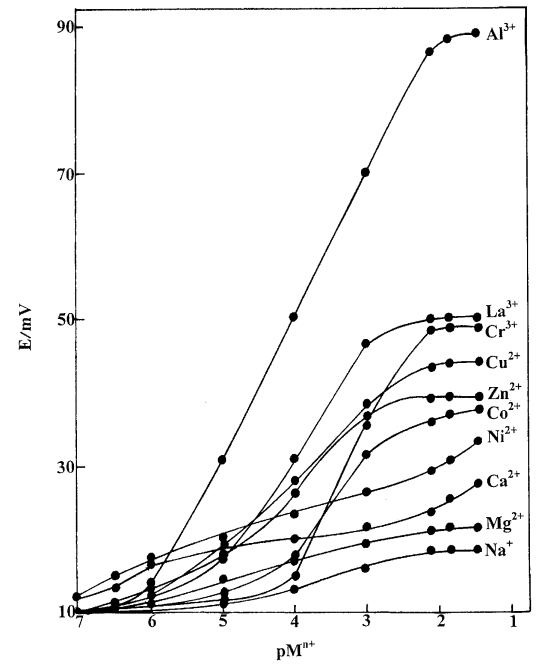

Fig. 5 Potential response for various TX5 based PVC-membrane electrodes. The membrane composition was: $32 \%$ PVC, $58 \%$ NPOE, $3 \%$ TX $5,7 \%$ OA.

However, $\mathrm{Al}^{3+}$ ion with the most sensitive response over a wide concentration range could be suitably determined with the membrane electrode based on TX5. This is most probably

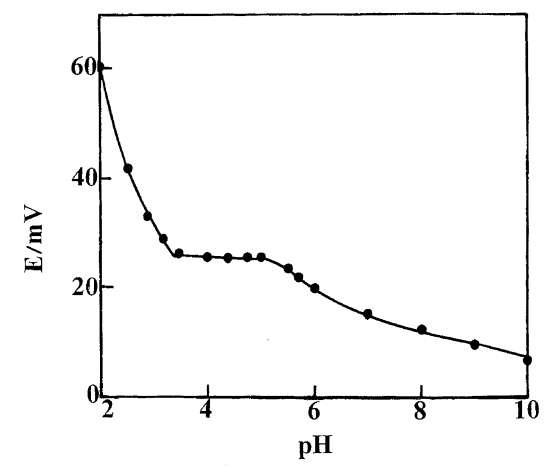

Fig. 6 Effect of the $\mathrm{pH}$ of the test solution on the potential response of an $\mathrm{Al}^{3+}$-selective electrode based on TX5.

mainly due to the highly selective behavior of the ionophore for $\mathrm{Al}^{3+}$ over other metal ions.

The sensitivity and selectivity of the ion-selective membrane electrodes are well known to depend not only on the nature of ionophore, but also significantly on the membrane composition

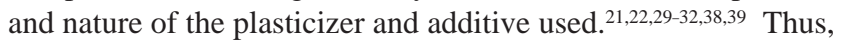
the influences of the membrane composition and the nature and amount of the plasticizer and additive on the potential response of the $\mathrm{Al}^{3+}$ sensor were investigated. The results are summarized in Table 2. Because of the effect of the nature of the plasticizer on the dielectric constant of the membrane phase, the mobility and state of ionophores, ${ }^{38-40}$ it was expected to play a key role in determining the ion-selective electrode characteristics. Table 2 shows that among three different plasticizers tested, the use of NPOE resulted in the best sensitivity and linear range. Moreover, $3 \%$ ionophore together with $7 \% \mathrm{OA}$, as a suitable additive, was selected for the preparation of an $\mathrm{Al}^{3+}$ ion-selective electrode with the optional performance characteristics. A comparison between the results given in Table 2 clearly indicates the superiority of OA over STPB, which is commonly employed as an additive in the preparation of PVC-membrane electrodes..$^{39,41-43}$ We have recently reported the first use of a fatty acid, such as OA, as a very suitable lipophilic additive for including permselectivity to some PVC-membrane selective electrodes. As is obvious from Table 2, the membrane obtained with the PVC/NPOE/TX5/OA percent ratio of $32 / 58 / 3 / 7$ (number 3) resulted in the best potentiometric response.

The proposed $\mathrm{Al}^{3+}$ electrode was examined at different concentrations of the inner reference solution. The concentration of $\mathrm{Al}^{3+}$ ion in the internal solution was varied from $1.0 \times 10^{-2}$ to $1.0 \times 10^{-4} \mathrm{M}$ and the potential response of the 


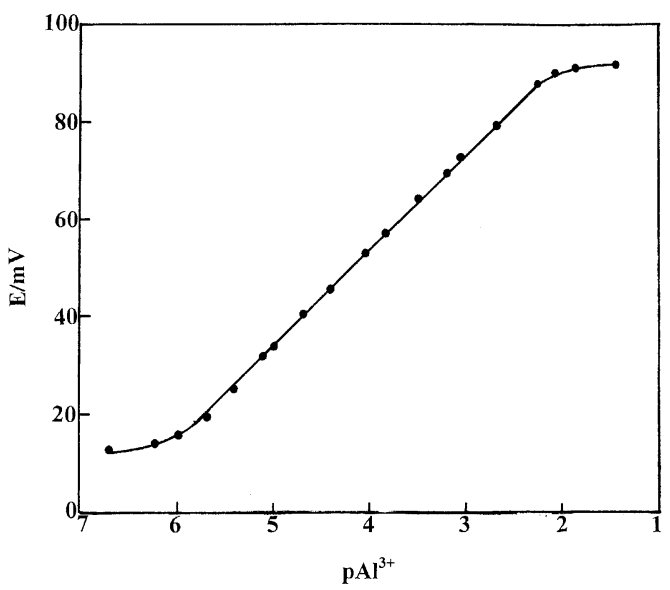

Fig. 7 Calibration graph for an $\mathrm{Al}^{3+}$-selective electrode based on TX5. The membrane composition was: $32 \%$ PVC, 58\% NPOE, 3\% TX5, $7 \%$ OA.

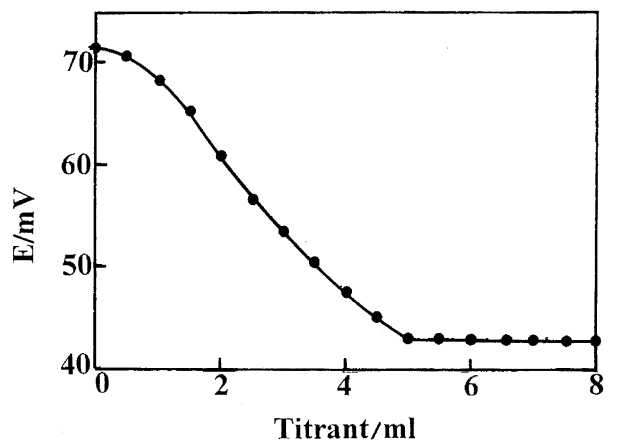

Fig. 8 Potentiometric titration curve of $50 \mathrm{ml}$ of a $1.0 \times 10^{-3} \mathrm{M} \mathrm{Al}^{3+}$ solution with $1.0 \times 10^{-2} \mathrm{M}$ EDTA at $\mathrm{pH} 5.0$, using the proposed sensor as an indicator electrode.

electrode was measured. It was found that the variation of the concentration of internal solution did not cause any significant difference in the electrode's potential response, except for an expected change in the intercept of the calibration curves. A 1.0 $\times 10^{-3} \mathrm{M}$ concentration of $\mathrm{Al}\left(\mathrm{NO}_{3}\right)_{3}$ is quite appropriate for proper functioning of the electrode.

The optimum equilibration time for the proposed membrane electrode in a $1.0 \times 10^{-2} \mathrm{M} \mathrm{Al}\left(\mathrm{NO}_{3}\right)_{3}$ solution is $24 \mathrm{~h}$, after which it generated a stable potential in contact with $\mathrm{Al}^{3+}$ ion solutions. They have a very fast response time. The average time required for the electrode to reach a potential within \pm 1 $\mathrm{mV}$ of the final equilibrium value after successive addition of a series of $\mathrm{Al}^{3+}$ solutions, each having a tenfold difference in concentration, was determined over the entire calibration range. The thus-obtained response times were found to be $5 \mathrm{~s}$ or less, over the entire calibration range. The prepared membrane electrodes could be used for at least 3 months without any measurable divergence in their potential responses.

The $\mathrm{pH}$ dependence of the proposed $\mathrm{Al}^{3+}$-selective membrane sensor was investigated at a $1.0 \times 10^{-4} \mathrm{M} \mathrm{Al}^{3+}$ over a $\mathrm{pH}$ range of $2.0-10.0$, maintained by a drop-wise addition of concentrated solutions of either $\mathrm{HCl}$ or $\mathrm{NaOH}$. The results are shown in Fig. 6. As can be seen, the potential remains constant over a $\mathrm{pH}$ range of $3.4-5.0$, which can be used as the working $\mathrm{pH}$ range of the proposed electrode. Meanwhile, the observed potential increase below $\mathrm{pH} 3.4$ can be ascribed to the
Table 3 Potentiometric selectivity coefficients of various interfering ions

\begin{tabular}{llll}
\hline $\mathrm{M}^{\mathrm{n}+}$ & $K_{\mathrm{A}, \mathrm{B}}^{\mathrm{MPM}}$ & $\mathrm{M}^{\mathrm{n}+}$ & $K_{\mathrm{A}, \mathrm{B}}^{\mathrm{MPM}}$ \\
\hline $\mathrm{Li}^{+}$ & $2.0 \times 10^{-4}$ & $\mathrm{Cd}^{2+}$ & $3.6 \times 10^{-4}$ \\
$\mathrm{Na}^{+}$ & $6.4 \times 10^{-4}$ & $\mathrm{Ga}^{2+}$ & $1.0 \times 10^{-4}$ \\
$\mathrm{~K}^{+}$ & $2.0 \times 10^{-4}$ & $\mathrm{Mn}^{2+}$ & $5.0 \times 10^{-4}$ \\
$\mathrm{Ca}^{2+}$ & $1.8 \times 10^{-4}$ & $\mathrm{~Pb}^{2+}$ & $7.2 \times 10^{-4}$ \\
$\mathrm{Mg}^{2+}$ & $3.6 \times 10^{-4}$ & $\mathrm{Hg}^{2+}$ & $2.2 \times 10^{-3}$ \\
$\mathrm{Sr}^{2+}$ & $2.1 \times 10^{-5}$ & $\mathrm{La}^{3+}$ & $3.8 \times 10^{-4}$ \\
$\mathrm{Co}^{2+}$ & $2.2 \times 10^{-5}$ & $\mathrm{Ce}^{2+}$ & $9.6 \times 10^{-4}$ \\
$\mathrm{Ni}^{2+}$ & $7.2 \times 10^{-4}$ & $\mathrm{In}^{3+}$ & $1.2 \times 10^{-4}$ \\
$\mathrm{Zn}^{2+}$ & $2.3 \times 10^{-5}$ & $\mathrm{Fe}^{3+}$ & $1.3 \times 10^{-2}$ \\
$\mathrm{Cu}^{2+}$ & $2.0 \times 10^{-3}$ & $\mathrm{Cr}^{3+}$ & $4.0 \times 10^{-3}$ \\
\hline
\end{tabular}

interference of $\mathrm{H}^{+}$ion, and the diminished potential of the electrode at $\mathrm{pH}>5.0$ is most probably due to the formation of some aluminum hydroxide species.

The PVC-membrane electrode prepared and operated under optimal experimental conditions shows a linear response to the activity of $\mathrm{Al}^{3+}$ ion in the range of $2.0 \times 10^{-2}$ to $2.0 \times 10^{-6} \mathrm{M}$ (Fig. 7), with a Nernstian slope of $19.7 \pm 0.3 \mathrm{mV}$ per decade aluminum ion concentration $(n=6)$. The limit of detection, as determined from the intersection of the two segments of the calibration graph, was $1.0 \times 10^{-6} \mathrm{M}$. The standard deviation of ten replicate potential measurements was $\pm 0.4 \mathrm{mV}$.

The selectivity behavior, usually expressed in terms of the potentiometric selectivity coefficients, is obviously one of the most important characteristics of an ion-selective electrode, which is the relative electrode response for the primary ion over other ions present in solution. To investigate the selectivity of the proposed membrane electrode, its potential response was investigated in the presence of various interfering cations using the matched potential method (MPM). ${ }^{44}$ This method is recommended for eliminating the limitations of the corresponding methods based on the Nikolski-Eisenman equation for determining the potentiometric selectivity coefficients. These limitations include a non-Nernstian behavior of interfering ions, an inequality of charges of any primary and interfering ions and the activity dependence of the potential values. ${ }^{44,45}$

According to the MPM, ${ }^{44}$ the selectivity coefficients are defined as the activity, the ratio of the primary ion (A) and the interfering ion (B) that gives the same potential change in a reference solution. Thus, one can measure the change in the potential upon changing the primary ion activity. Then, the interfering ion would be added to an identical reference solution until the same potential change is obtained. The MPM selectivity is then determined as $K_{\mathrm{A}, \mathrm{B}}^{\mathrm{MPM}}=a_{\mathrm{A}} / a_{\mathrm{B}}$.

The experimental conditions used for the determination of $K_{\mathrm{A}, \mathrm{B}}^{\mathrm{MPM}}$ were as follows: reference solution, $2.0 \times 10^{-6} \mathrm{M}$ $\mathrm{Al}\left(\mathrm{NO}_{3}\right)_{3}$; primary ion $(\mathrm{A}), 1.0 \times 10^{-5}-1.0 \times 10^{-4} \mathrm{M} \mathrm{Al}^{3+}$; interfering ion $(\mathrm{B}), 1.0 \times 10^{-2} \mathrm{M} \mathrm{M}^{n+}$. The resulting $K_{\mathrm{A}, \mathrm{B}}^{\mathrm{MPM}}$ values for the proposed $\mathrm{Al}^{3+}$ ion-selective electrodes are listed in Table 3. As can be seen, for the case of most cations tested, the selectivity coefficients are in the order of $10^{-4} \mathrm{M}$ or lower. However, only in minor cases are the selectivity coefficients greater than $10^{-4}\left(2.0 \times 10^{-3}\right.$ for $\mathrm{Hg}^{2+}, 2.0 \times 10^{-3}$ for $\mathrm{Cu}^{2+}, 4.0 \times$ $10^{-3}$ for $\mathrm{Cr}^{3+}$ and $1.3 \times 10^{-2}$ for $\mathrm{Fe}^{3+}$ ). The results seem to indicate that, even in the case of $\mathrm{Hg}^{2+}, \mathrm{Cu}^{2+}, \mathrm{Cr}^{3+}$ and $\mathrm{Fe}^{3+}$ ions, the disturbance produced by the interfering cations in the functioning of the proposed electrodes is negligible.

The proposed $\mathrm{Al}^{3+}$ ion-selective electrode was found to work well under laboratory conditions. It was used as an indicator 
Table 4 Recovery of different amounts of $\mathrm{Al}^{3+}$ from tap water ${ }^{\mathrm{a}}$

\begin{tabular}{crc}
\hline \multicolumn{2}{c}{ Concentration $/ \mu \mathrm{g} \mathrm{m}^{-1}$} & \\
\cline { 1 - 2 } Added & \multicolumn{1}{c}{ Found $^{\mathrm{b}}$} & Recovery, \% \\
\hline 10.0 & $9.8 \pm 0.2$ & 98.0 \\
25.0 & $25.2 \pm 0.2$ & 100.8 \\
50.0 & $49.7 \pm 0.3$ & 99.4 \\
100.0 & $100.3 \pm 0.2$ & 100.3 \\
\hline
\end{tabular}

a. The $\mathrm{pH}$ of sample was adjusted to 5.0 using a citrate buffer. b. Average of three replicate measurements.

electrode for the titration of $50.0 \mathrm{ml}$ of $1.0 \times 10^{-3} \mathrm{Al}^{3+}$ with a $0.01 \mathrm{M}$ EDTA at $\mathrm{pH}=5$ (adjusted by a citrate buffer). The resulting titration curve is shown in Fig. 8. As can be seen, the amount of aluminum ions can be accurately determined with the proposed electrode.

The applicability of the proposed electrode was tested by its use in recovery studies of different concentrations of aluminum nitrate from tap water. The results are summarized in Table 4. As is obvious, at all concentration levels, the recovery of $\mathrm{Al}^{3+}$ was quantitative. The electrode was also successfully applied to the direct determination of aluminum in waste stone samples obtained from Arak Aluminum Production Factory (Arak, Iran). After $1.00 \mathrm{~g}$ of a crushed sample was dissolved, its solution was prepared, as described elsewhere. ${ }^{21}$ The aluminum content of the solution was determined by the proposed sensor using the calibration curve method. The aluminum content obtained from three replicate measurements, $0.52 \pm 0.02 \%$, was found to be in satisfactory agreement with that obtained by atomic absorption spectrometry, $0.50 \pm 0.01 \%$.

\section{References}

1. M. Hofer and L. Shuker, Food Chem. Toxicol., 2000, 38, 53.

2. Council Directive 98/83/EC of 3 November 1998 on the Quality of Water Intended for Human Consumption, Official J. L, 1998, 330, 32.

3. Directive 2000/60/EC of the European Parliament and the Council of 23 October 2000 Establishing a Framework for Community Action in the Field of Water Policy, Official J. $L, 2000,327,1$.

4. P. F. Good, C. W. Olanow, and D. P. Perl, Brain Res., 1992, 593, 343.

5. M. Kawahara, K. Muramoto, K. Kobayashi, H. Mori, and Y. Kroda, Biochem. Biophys. Res. Commun., 1994, 198, 531.

6. J.-L. Lin, M.-T. Kou, and M.-L. Leu, Nephron, 1996, 74, 33.

7. S. R. Paik, J.-H. Lee, D.-H. Kim, C.-S. Chang, and J. Kim, Arch. Biochem. Biophys., 1997, 344, 325.

8. T. P. Flaten, Brain Res. Bull., 2001, 55, 187.

9. J. A. Resing and C. I. Measures, Anal. Chem., 1994, 66, 4105.

10. C. Huang and H. Shiu, Colloids Surf. A: Physicochem. Eng. Aspects, 1996, 113, 155.

11. C. Brach-Papa, B. Coulomb, J.-L. Baudenne, V. Cerda, and F. Theraulaz, Anal. Chim. Acta, 2002, 457, 311.

12. N. N. Greenwood and A. Earnshaw, "Chemistry of the Elements", 1984, Pergamon, New York.
13. N. Clarke, L. G. Danielsson, and A. Sparen, Pure Appl. Chem., 1996, 68, 1597.

14. X. Wang, J. Lei, S. Bi, N. Gan, and Z. Wei, Anal. Chim. Acta, 2001, 449, 35.

15. G. J. Moody, B. B. Saad, and D. R. Thomas, Sel. Electrode Rev., 1988, 71, 10.

16. Y. Umezawa, "CRC Handbook of Ion-Selective Electrodes", 1990, CRC Press, Boca Raton, FL.

17. J. Janata, M. Josowics, P. Vanysek, and Devaney, Anal. Chem., 1998, 70, 179R.

18. P. Bühlmann, E. Pretsch, and E. Bakker, Chem. Rev., 1998, 98, 1593.

19. R. C. Misra and M. C. Chattopadhyaya, J. Indian Chem. Soc., 1989, 66, 54.

20. V. L. Volkov and O. I. Gyrdasova, Zh. Anal. Khim., 1995, 50, 595.

21. M. B. Saleh, S. M. Hassan, A. A. Abdel Gaber, and N. A. Abdel Kream, Anal. Chim. Acta, 2001, 434, 247.

22. A. Abbaspour, A. R. Esmaeillbeig, A. A. Jarrahpour, B. Khajeh, and R. Kia, Talanta, 2002, 58, 397.

23. J. K. Moon, J. W. Park, W. S. Lee, and Y. Yoon, J. Heterocyclic Chem., 1999, 36, 793.

24. B.-J. Fioster, R. A. Wiegand, S. Pugh, and T. H. Corbett, Clin. Cancer Res., 1997, 3, 2047.

25. C. Roffey, "Photogeneration of Reactive Species for $U V$ Curing", 1997, Wiley, Sussex.

26. J. P. Fouassier, D. Ruhlman, B. Graft, F. Morlet-Savary, and W. Wieder, Prog. Org. Coat., 1995, 25, 235.

27. T. Corrales, F. Catalina, C. Peinado, N. S. Allen, A. M. Rufs, C. Bueno, and M. V. Encinas, Polymer, 2002, 43, 4591.

28. M. V. Encinas, A. M. Rufs, T. Corrales, F. Catalina, C. Peinado, K. Schmith, M. G. Neumann, and N. S. Allen, Polymer, 2002, 43, 3909.

29. M. Shamsipur, M. Yousefi, and M. R. Ganjali, Anal. Chem., 2000, 72, 2391.

30. A. R. Fakhari, M. Alaghemand, and M. Shamsipur, Anal. Lett., 2001, 34, 1097.

31. M. Shamsipur, M. Yousefi, M. Hosseini, and M. R. Ganjali, Anal. Chem., 2002, 74, 5538.

32. M. R. Ganjali, L. Naji, T. Poursaberi, M. Shamsipur, and S. Hghgoo, Anal. Chim. Acta, 2003, 475, 59.

33. A. R. Salimi, MSc Thesis, Shiraz University, Shiraz, Iran, 2000.

34. S. Kamata, Y. Kubo, H. Murata, and A. Bhale, Analyst, 1989, 114, 1029.

35. R. Winkler, Struct. Bonding [Berlin], 1972, 10, 1.

36. J. Ghasemi and M. Shamsipur, J. Coord. Chem., 1995, 36, 183.

37. V. A. Nicely and J. L. Dye, J. Chem. Educ., 1971, 49, 443.

38. X. Yang, N. Kumar, H. Chi, D. B. Hibbert, and P. W. Alexander, Electroanalysis, 1997, 9, 549.

39. E. Bakker, P. Bühlmann, and E. Pretsch, Chem. Rev., 1997, 97, 3083.

40. A. Hodinar and A. Jyo, Anal. Chem., 1989, 61, 1169.

41. R. Eugster, P. M. Gehring, W. E. Morf, U. Spichiger, and W. Simon, Anal. Chem., 1991, 63, 2285.

42. T. Rosatzin, E. Bakker, K. Suzuki, and W. Simon, Anal. Chim. Acta, 1993, 280, 197.

43. U. Schaller, E. Bakker, U. E. Spichiger, and E. Pretsch, Anal. Chem., 1994, 66, 391.

44. Y. Umezawa, K. Umezawa, and H. Sato, Pure Appl. Chem., 1995, 67, 507.

45. E. Bakker, Electroanalysis, 1997, 9, 7. 